\title{
Nutritional Situation of the Elderly in Eastern/Baltic and Central/Western Europe - The AgeingNutrition Project
}

\author{
Stephanie Lesser Lioba Pauly Dorothee Volkert Peter Stehle \\ for the AgeingNutrition Group ${ }^{1}$ \\ IEL - Nutritional Physiology, University of Bonn, Bonn, Germany
}

\section{Key Words}

Elderly $\cdot$ Nutrition and health status $\cdot$ Europe $\cdot$ Seniors .

Energy intake $\cdot$ Body mass index $\cdot$ Nutrient intake

\begin{abstract}
Background/Aims: In the AgeingNutrition project, funded by the European Commission, partners from 10 'Eastern/Baltic' (new) European (Bulgaria, Czech Republic, Estonia, Hungary, Latvia, Poland, Romania, Slovak Republic, Slovenia, and Turkey) and 5 'Central/Western' (old) European countries (Austria, Belgium, Germany, Greece, and Spain) performed a comparative analysis of existing data on nutritional status, food intake, nutrient intake, dietary habits and lifestyle of the aging population in Europe. Methods: Using predefined inclusion criteria, 36 studies (22 from Eastern/Baltic, 14 from Central/Western countries) were chosen for evaluation. The studies varied in general design, data assessment and parameters and methods applied (especially regarding assessment of nutritional situation, comprising anthropometry, blood lipid profile, dietary nutrient and food intake). Thus, data evaluation by recalculation of raw data had to be restricted to a few distinct, common parameters. Results and Conclusion: Energy intake is too high in both regions, especially in some of the 'younger old' and seems not to be adjusted to energy expenditure. Simultaneously, energy intake was considerably lower than recommended in some very
\end{abstract}

old seniors in Eastern/Baltic countries. Interestingly, quantity and quality of available information is similar in 'new' and 'old' member states. Immense variations in methodology hampered performing reliable comparative evaluation. It is, thus, mandatory to standardize methods for assessment of nutrition and health status for future international multicenter studies.

Copyright $\odot 2008$ S. Karger AG, Basel

\begin{abstract}
The AgeingNutrition Group: Ibrahim Elmadfa, Karin Haas, Institute of Nutritional Sciences, University of Vienna (Austria). Ghislaine Dufourny, Philippe Dricot, Haute Ecole Lucia de Brouckère, CIRIHA, Bruxelles (Belgium). Vesselka Duleva, Nikolay Rizov, National Center of Hygiene, Medical Ecology and Nutrition, Sofia (Bulgaria). Pavol Hlubik, Purkyne Military Medical Academy, Hradec Kralove (Czech Republic). Margus Lember, Department of Internal Medicine, University of Tartu (Estonia). Peter Stehle, Dorothee Volkert, Stephanie Lesser, Lioba Pauly, IEL - Nutritional Physiology. University of Bonn (Germany). Anthony Kafatos, Preventive Medicine \& Nutrition Unit, University of Crete (Greece). István Szabolcs, Maria Pankotai Gillengerné, Department of Dietetics, College of Health Care, Semmelweis University, Budapest (Hungary). Guntars Selga, Melita Sauka, Anita Villeruša, Riga Stradins University (Latvia). Wlodzimierz Sekula, Lucjan Szponar, Instytut Zywnosci iZywienia, Warsaw (Poland). Mariana Vlad, Environmental Health Department, 'Prof. Dr. Iuliu Moldovan' Institute of Public Health, Cluj-Napoca (Romania). Emilia Leskova, Jana Mosnačková, Food Research Institute, Bratislava (Slovak Republic). Marjan Simcic, Department of Food Science and Technology, University of Ljubljana (Slovenia). Angelo Gonzales, Roca Montse, Public Health Department, Ajuntament de Granollers (Spain). Emine Aksoydan, Department of Nutrition and Dietetics, Faculty of Health Science, Baskent University, Ankara (Turkey).
\end{abstract}

\section{KARGER}

Fax +41613061234 E-Mail karger@karger.ch www.karger.com
(C) 2008 S. Karger AG, Basel

0250-6807/08/0525-0062\$24.50/0

Accessible online at:

www.karger.com/anm
Prof. Dr. Peter Stehle

IEL - Nutritional Physiology, University of Bonn

Endenicher Allee 11-13

DE-53115 Bonn (Germany)

Tel. +49 22873 3680, Fax +49 22873 3217, E-Mail p.stehle@uni-bonn.de 


\section{Introduction}

Balanced nutrition covering nutrient demands and an adequate lifestyle are important factors for healthy aging. Older persons ( $\geq 60$ years) currently represent $20 \%$ of the total European population [1]. EU-wide information about lifestyle and food/nutrient intake is mandatory to define political strategies supporting/facilitating adequate, health-promoting behavior. Nevertheless, pan-European information is scarce [2]. The nutritional situation of elderly in Central/Western EU countries has been described in the multicentre SENECA study [3] using uniform methodology, or by compiling national data (European Nutrition and Health Report, ENHR [4]). Additionally, several nationwide, regional and local surveys using different methods and study design were performed. In contrast, at the beginning of the AgeingNutrition project, the nutritional situation in Eastern/Baltic (new) EU countries was not transparent; the number of studies performed was not known, as most data were not published or only published nationally in the respective mother language. Only one of the new European countries (Hungary) has been included in the former ENHR.

Thus, project aims were to compile existing data on nutritional status, food/nutrient intake, dietary habits and lifestyle of the aging population in Europe; to comparatively analyze data available from the Central/Western and the 'new' Eastern/Baltic EU Member states on the basis of actual recommendations; and, finally, to define recommendations for future research activities.

\section{Methods}

Partners from 10 'Eastern/Baltic' (new) European (Bulgaria, Czech Republic, Estonia, Hungary, Latvia, Poland, Romania, Slovak Republic, Slovenia, and Turkey) and 5 'Central/Western' (old) European countries (Austria, Belgium, Germany, Greece, and Spain) compiled and checked all national data (published and unpublished) on nutrition and lifestyle of the elderly population. After this first check, study categories and mandatory variables as 'inclusion criteria' for comparative analysis were defined ${ }^{2}$ (table 1). Country-specific data masks for data entry were designed. If necessary, data were translated into English before transmission to the Data Analysis Group. Where possible, raw data of the studies were collected and compiled. To meet a common data presentation scheme, e.g. age groups divided in decades from 55 years

2 The Data Analysis Group of AgeingNutrition was formed by project members from Austria, Belgium, Germany, Greece, Hungary, and the Slovak Republic.

AgeingNutrition Project
Table 1. Inclusion criteria for studies considered in the AgeingNutrition project

Study inclusion criteria

- Cross-sectional study design

- Study data not older than 10 years

- Participants not younger than 55 years

- Reasonable number of participants in age subgroups $(n>15)$

- Free-living elderly in urban and/or rural areas

- Not too specific study population

(e.g. only persons with osteoarthritis)

- Nursing home residents included (facultative)

- Relevance of parameters

- Detailed data accessible/available

onwards, available raw data were recalculated if necessary. Finally, on the basis of the most comprehensive and apt study from each project member country, comparative analyses of data on nutritional status, food intake, nutrient intake, dietary habits and lifestyle of the aging population in Europe was performed. Due to broad methodological variations in included studies, the Data Analysis Group decided to abstain from statistical evaluations of differences and process and present data in a descriptive manner.

The final report includes results of the EU-wide comparative analyses as well as national aspects (www.public-health.tu-dresden.de/dotnetnuke3/Projects/)

\section{Results}

Study data were available in all participating countries ( $\mathrm{n}=69$ studies). Available studies were checked first on the inclusion criteria (table 1). Thirty-six adequate studies were chosen for further data compilation (table 2). Studies were checked on the parameters assessed. The potential for comparative evaluation was found to be limited to few parameters because of great differences in study design, methods and parameters applied in the studies. Mandatory basic characteristics of participants covered social situation and health status. Nutritional status was ascertained by use of anthropometric data and blood lipids. Information on lifestyle comprised physical activities, smoking and use of alcoholic beverages. Dietary habits were characterized by meal frequency and use of supplements. Food intake was recorded by use of different methods: food frequency (FFQ), 24-hour recall, or 3-day estimated record (see table 6); nutrients intake was entered the way it had been calculated by the national study coordinators (thereby, several different food data composition tables had been used).

Ann Nutr Metab 2008;52(suppl 1):62-71 
Table 2. Country of origin of included studies

\begin{tabular}{llll}
\hline Country & $\begin{array}{l}\text { Number } \\
\text { of studies }\end{array}$ & Country & $\begin{array}{l}\text { Number } \\
\text { of studies }\end{array}$ \\
\hline Bulgaria & 1 & Austria & 3 \\
Czech Republic & 3 & Belgium & 1 \\
Estonia & 2 & Germany & 2 \\
Hungary & 3 & Greece & 4 \\
Latvia & 2 & Spain & 4 \\
Poland & 1 & & \\
Romania & 4 & & \\
Slovak Republic & 2 & & \\
Slovenia & 1 & & \\
Turkey & 3 & Central/ & \\
\hline Eastern/ & & Western Europe & 14 \\
Baltic Europe & 22 & & \\
\hline
\end{tabular}

From every participating country, one comprehensive study was chosen for comparative evaluation.

\section{Nutritional Status: Anthropometry}

Body mass indices (BMI) were recorded. Data from most countries have been assessed by measurement (body height and weight) in the course of national studies (data from Bulgaria, Latvia, Slovenia, Austria, and Belgium were assessed by means of a questionnaire; Estonia: method unknown). Mean BMI values of age groups are similar in all countries studied (data not shown). Table $3 a, b$ shows the percentages of women/men with BMI $<20$ (indicating underweight [5]), and $\geq 30$ (indicating obesity). Prevalence of obesity was observed to be greater than $10 \%$ in all countries and nearly all age groups (up to $25 \%$ and even more). At the same time, BMI values of $<20$ were observed in significant percentages in Romanian 'youngest old' men and in a quarter of 104 oldest Belgian women. Generally, prevalence of underweight increased and the prevalence of obesity decreased with age.

\section{Nutritional Status: Blood Lipids}

In general, mean blood lipid profiles are within an acceptable range, as derived from Czech, Romanian, Slovakian, Austrian and Greek data (table 4). Women had a higher plasma cholesterol level than men. But this was mainly due to a higher portion of HDL-cholesterol, as indicated by satisfying average ratios of total:HDL-cholesterol. Raw data of blood lipid level were re-evaluated by using cut-off values (reference values) for lipid metabolism established for primary prevention of cardiovascu- lar diseases [6] in Austria. Table 5 illustrates that in both regions are varying percentages of elderly whose blood lipids do not meet the criteria for primary prevention.

\section{Lifestyle}

In summary, men seem to be involved in physical activities more often than women. $60-70 \%$ of Slovakian, Slovenian and Belgian elderly people but only $20-50 \%$ of Estonian, Latvian, German and Greek seniors report being physically active 1-2 times a week. One exception was Austria, where most of the elderly people ( 90\%) exercise physically once or twice a week. No geographical pattern between Eastern/Baltic and Central/Western countries in sports activities of elderly people can be figured out from AgeingNutrition data.

Smoking and consumption of alcoholic drinks seem to be more common in elderly men than in women. Answer modes for smoking habits varied broadly between studies. In Eastern/Baltic countries, $88-97 \%$ of women assessed were nonsmokers, but the nonsmoking rate in men varied widely from $85 \%$ (Slovenia) to $27 \%$ (Latvia). In Central/Western countries, more women (35-94\%) than men (16-43\%) have never smoked, and more than $70 \%$ of people are now nonsmokers (one exception: only $\sim 45 \%$ of Greek old men do not smoke, $n=31$ ). Thus, smoking seems to be more common in elderly men in Eastern/Baltic than Central/Western countries. The percentage of alcohol 'consumers' varied from country to country without obvious differences between the regions.

\section{Dietary Intake}

Food consumption was assessed using a variety of methods (table 6). 24-hour recall was applied most frequently. Although recent studies were consulted, data were assessed during different time periods, and thus the comparison has to be interpreted cautiously.

Some country-specific food patterns are obvious (fig. 1-4). Differences between countries are quite evident (e.g. consumption of milk products in Poland is double that of Romania), but may either be due to differences in consumption or in data assessment. In general, the level of total intake appears to be quite low in some countries. In Poland, Romania, and Bulgaria, food intake seems to decrease slightly with increasing age in women (except for Turkey). This effect is even more evident in men from these countries (fig. 3). General differences between 'new' and 'old' member states cannot be seen.

Nutrient intake was calculated from dietary assessment. Data in table $7 \mathrm{a}, \mathrm{b}$ are ranges of means. Energy 
Table 3a. Prevalence (\%) of underweight (BMI <20) and obesity $(\mathrm{BMI} \geq 30)$ in women

\begin{tabular}{|c|c|c|c|c|}
\hline & \multirow{2}{*}{$\begin{array}{l}\text { Age group } \\
\text { years }\end{array}$} & \multirow[t]{2}{*}{ Number } & \multicolumn{2}{|c|}{ BMI classification, $\%$} \\
\hline & & & $<20$ & $\geq 30$ \\
\hline \multicolumn{5}{|l|}{ Eastern/Baltic } \\
\hline \multirow[t]{2}{*}{ Bulgaria $^{b}$} & $60-75$ & 194 & $\mathrm{NA}^{\mathrm{a}}$ & 16 \\
\hline & $\geq 75$ & 113 & NA & 16 \\
\hline Czech Republic & 55-64 & 67 & 2 & 42 \\
\hline Estonia $^{\mathrm{b}}$ & 55-65 & 77 & 7 & 20 \\
\hline Hungary ${ }^{b}$ & $\geq 65$ & 155 & NA & 25 \\
\hline Latvia ${ }^{b}$ & $55-64$ & 278 & NA & 30 \\
\hline \multirow{4}{*}{ Poland } & $55-64$ & 185 & 2 & 37 \\
\hline & $65-74$ & 191 & 3 & 36 \\
\hline & $75-84$ & 61 & 8 & 33 \\
\hline & $\geq 85$ & 12 & 0 & 17 \\
\hline \multirow[t]{3}{*}{ Romania } & 55-64 & 77 & 5 & 35 \\
\hline & $65-74$ & 61 & 2 & 30 \\
\hline & $75-84$ & 12 & 8 & 8 \\
\hline \multirow[t]{4}{*}{ Slovakia } & $55-64$ & 2,545 & 2 & 29 \\
\hline & $65-74$ & 1,350 & 2 & 29 \\
\hline & $75-84$ & 342 & 5 & 20 \\
\hline & $\geq 85$ & 12 & 0 & 8 \\
\hline \multirow[t]{3}{*}{ Slovenia } & $55-64$ & 29 & 0 & 21 \\
\hline & $65-74$ & 7 & 0 & 14 \\
\hline & $75-84$ & 3 & 33 & 0 \\
\hline \multirow[t]{3}{*}{ Turkey } & $65-74$ & 458 & 2 & 55 \\
\hline & $75-84$ & 149 & 5 & 42 \\
\hline & $\geq 85$ & 17 & 12 & 29 \\
\hline \multicolumn{5}{|l|}{ Central/Western } \\
\hline \multirow[t]{4}{*}{ Austria } & $55-64$ & 99 & 2 & 22 \\
\hline & $65-74$ & 82 & 0 & 26 \\
\hline & $75-84$ & 117 & 1 & 17 \\
\hline & $\geq 85$ & 74 & 5 & 10 \\
\hline \multirow[t]{4}{*}{ Belgium } & $55-64$ & 665 & 8 & 17 \\
\hline & $65-74$ & 630 & 6 & 20 \\
\hline & $75-84$ & 359 & 9 & 17 \\
\hline & $\geq 85$ & 104 & 25 & 8 \\
\hline \multirow[t]{3}{*}{ Germany } & $65-74$ & 237 & 3 & 24 \\
\hline & $75-84$ & 172 & 7 & 20 \\
\hline & $\geq 85$ & 136 & 9 & 11 \\
\hline \multirow[t]{2}{*}{ Greece $^{b}$} & $65-74$ & 126 & 3 & 28 \\
\hline & $75-84$ & 38 & 0 & 100 \\
\hline \multirow[t]{3}{*}{ Spain $^{\mathrm{b}}$} & $55-64$ & 120 & 1 & 39 \\
\hline & $65-74$ & 93 & 1 & 39 \\
\hline & $\geq 75$ & NA & NA & NA \\
\hline
\end{tabular}

${ }^{\text {a }} \mathrm{NA}=$ Data not available.

b Raw data not available for recalculation.

intake is too high in both regions, especially in some of the 'younger old' and seemed not to be adjusted to energy expenditure. At the same time, in some very old seniors in the Eastern/Baltic countries, energy intake was con-
Table 3b. Prevalence (\%) of underweight (BMI <20) and obesity $(\mathrm{BMI} \geq 30)$ in men

\begin{tabular}{|c|c|c|c|c|}
\hline & \multirow{2}{*}{$\begin{array}{l}\text { Age group } \\
\text { years }\end{array}$} & \multirow[t]{2}{*}{ Number } & \multicolumn{2}{|c|}{ BMI classification, $\%$} \\
\hline & & & $<20$ & $\geq 30$ \\
\hline \multicolumn{5}{|l|}{ Eastern/Baltic } \\
\hline \multirow[t]{2}{*}{ Bulgaria $^{b}$} & $60-75$ & 186 & $\mathrm{NA}^{\mathrm{a}}$ & 12 \\
\hline & $\geq 75$ & 101 & NA & 6 \\
\hline Czech Republic & $55-64$ & 51 & 2 & 14 \\
\hline Estonia $^{\mathrm{b}}$ & $55-65$ & 55 & 0 & 11 \\
\hline Hungary ${ }^{b}$ & $\geq 65$ & 90 & NA & 27 \\
\hline Latvia ${ }^{b}$ & $55-64$ & 166 & NA & 16 \\
\hline \multirow[t]{4}{*}{ Poland } & $55-64$ & 139 & 1 & 27 \\
\hline & $65-74$ & 119 & 7 & 21 \\
\hline & $75-84$ & 39 & 5 & 8 \\
\hline & $\geq 85$ & 5 & 20 & 0 \\
\hline \multirow[t]{3}{*}{ Romania } & $55-64$ & 39 & 13 & 36 \\
\hline & $65-74$ & 36 & 6 & 19 \\
\hline & $75-84$ & 15 & 0 & 7 \\
\hline \multirow[t]{4}{*}{ Slovakia } & $55-64$ & 1,555 & 1 & 27 \\
\hline & $65-74$ & 699 & 1 & 23 \\
\hline & $75-84$ & 198 & 4 & 15 \\
\hline & $\geq 85$ & 7 & 0 & 0 \\
\hline \multirow[t]{3}{*}{ Slovenia } & 55-64 & 17 & 0 & 12 \\
\hline & $65-74$ & 14 & 0 & 0 \\
\hline & $75-84$ & 3 & 0 & 33 \\
\hline \multirow[t]{3}{*}{ Turkey } & $65-74$ & 346 & 5 & 19 \\
\hline & $75-84$ & 103 & 7 & 15 \\
\hline & $\geq 85$ & 15 & 7 & 13 \\
\hline
\end{tabular}

\begin{tabular}{lcrrr}
\hline Central/Western & & & & \\
Austria & $55-64$ & 13 & 0 & 23 \\
& $65-74$ & 13 & 8 & 23 \\
& $75-84$ & 16 & 0 & 13 \\
Belgium & $\geq 85$ & 16 & 6 & 6 \\
& $55-64$ & 663 & 2 & 20 \\
& $65-74$ & 545 & 2 & 17 \\
& $75-84$ & 295 & 4 & 13 \\
Germany & $\geq 85$ & 63 & 8 & 2 \\
& $65-74$ & 224 & 1 & 14 \\
Greece $^{\mathrm{b}}$ & $75-84$ & 96 & 1 & 12 \\
& $\geq 85$ & 54 & 6 & 9 \\
Spain $^{\mathrm{b}}$ & $65-74$ & 102 & 0 & 18 \\
& $75-84$ & 43 & 0 & 33 \\
& $55-64$ & 97 & 0 & 22 \\
& $65-74$ & 83 & 1 & 26 \\
& $\geq 75$ & 101 & $\mathrm{NA}$ & 6 \\
\hline
\end{tabular}

${ }^{\mathrm{a}} \mathrm{NA}=$ Data not available

${ }^{\mathrm{b}}$ Raw data not available for recalculation.

siderably lower than recommended. In Eastern/Baltic women, carbohydrate intake was too low, and it was even lower in Central/Western women. Dietary fiber intake did not meet the recommendations. In general, fat intake 
Table 4. Blood lipid status in Czech Republic, Romania, Slovakia, Austria and Greece ${ }^{\mathrm{a}}$

\begin{tabular}{|c|c|c|c|c|c|c|c|}
\hline & \multirow{2}{*}{$\begin{array}{l}\text { Age } \\
\text { group } \\
\text { years }\end{array}$} & \multicolumn{3}{|c|}{ Women } & \multicolumn{3}{|c|}{ Men } \\
\hline & & $\mathrm{n}$ & $\begin{array}{l}\text { total chol. } \\
\text { [mmol/l plasma }]\end{array}$ & $\begin{array}{l}\text { total chol./ } \\
\text { HDL-chol. }\end{array}$ & $\mathrm{n}$ & $\begin{array}{l}\text { total chol. } \\
{[\mathrm{mmol} / \mathrm{l} \text { plasma }]}\end{array}$ & $\begin{array}{l}\text { total chol./ } \\
\text { HDL-chol. }\end{array}$ \\
\hline Czech Republic & $55-64$ & 67 & $6.0 \pm 0.9$ & $4.8 \pm 2.3$ & 51 & $5.3 \pm 0.8$ & $6.4 \pm 8.3$ \\
\hline \multirow[t]{3}{*}{ Romania } & $55-64$ & 77 & $5.2 \pm 1.3$ & $4.8 \pm 2.2$ & 39 & $4.9 \pm 1.1$ & $4.8 \pm 2.2$ \\
\hline & $65-74$ & 61 & $5.2 \pm 1.3$ & $4.4 \pm 2.0$ & 36 & $5.1 \pm 1.1$ & $4.2 \pm 2.4$ \\
\hline & $75-84$ & 12 & $4.7 \pm 1.1$ & $3.1 \pm 0.7$ & 15 & $3.8 \pm 1.1$ & $3.5 \pm 1.1$ \\
\hline \multirow[t]{4}{*}{ Slovakia } & $55-64$ & & $5.5 \pm 1.0(\mathrm{n}=2,817)$ & $4.1 \pm 2.1(\mathrm{n}=1,746)$ & & $5.1 \pm 1.0(\mathrm{n}=1,693)$ & $4.5 \pm 2.0(\mathrm{n}=1,183)$ \\
\hline & $65-74$ & & $5.5 \pm 1.0(\mathrm{n}=1,510)$ & $4.0 \pm 1.9(\mathrm{n}=843)$ & & $5.0 \pm 1.0(\mathrm{n}=795)$ & $4.3 \pm 2.4(\mathrm{n}=417)$ \\
\hline & $75-84$ & & $5.3 \pm 1.0(\mathrm{n}=381)$ & $4.0 \pm 1.8(\mathrm{n}=211)$ & & $4.8 \pm 0.8(\mathrm{n}=232)$ & $4.1 \pm 2.3(\mathrm{n}=113)$ \\
\hline & $\geq 85$ & & $5.3 \pm 1.4(\mathrm{n}=14)$ & $2.9 \pm 0.9(\mathrm{n}=9)$ & & $4.6 \pm 0.9(n=9)$ & $5.9 \pm 4.1(\mathrm{n}=3)$ \\
\hline \multirow[t]{4}{*}{ Austria } & $55-64$ & 81 & $5.6 \pm 1.0$ & $4.4 \pm 1.4$ & 9 & $5.2 \pm 0.7$ & $5.0 \pm 1.4$ \\
\hline & $65-74$ & 45 & $5.7 \pm 0.8$ & $4.2 \pm 1.5$ & 10 & $5.2 \pm 1.1$ & $5.0 \pm 1.6$ \\
\hline & $75-84$ & 47 & $5.8 \pm 1.0$ & $4.4 \pm 1.5$ & 8 & $5.4 \pm 1.0$ & $4.3 \pm 0.6$ \\
\hline & $\geq 85$ & 20 & $5.9 \pm 1.2$ & $4.0 \pm 0.8$ & 4 & $4.5 \pm 0.8$ & $4.9 \pm 1.2$ \\
\hline \multirow[t]{2}{*}{ Greece $^{b}$} & $65-74$ & 126 & $5.6 \pm 0.9$ & $4.4 \pm 1.3$ & 102 & $5.4 \pm 1.0$ & $4.9 \pm 1.2$ \\
\hline & $75-84$ & 38 & $5.6 \pm 1.0$ & $4.1 \pm 1.1$ & 43 & $5.1 \pm 0.9$ & $5.7 \pm 1.3$ \\
\hline \multicolumn{2}{|c|}{ Reference value [6] } & & $<5.2$ & $<5$ & & $<5.2$ & $<5$ \\
\hline
\end{tabular}

Table 5. Prevalence (\%) of blood lipids within range of reference value in Czech Republic, Romania, Slovakia, Austria and Greece ${ }^{\text {a }}$

\begin{tabular}{|c|c|c|c|c|c|c|c|}
\hline & \multirow{2}{*}{$\begin{array}{l}\text { Age group } \\
\text { years }\end{array}$} & \multicolumn{3}{|c|}{ Women } & \multicolumn{3}{|c|}{ Men } \\
\hline & & $\mathrm{n}$ & $\begin{array}{l}\text { total chol. }(\%) \\
<5.2 \mathrm{mmol} / 1\end{array}$ & $\begin{array}{l}\text { total chol./ } \\
\text { HDL-chol. }(\%)<5\end{array}$ & $\mathrm{n}$ & $\begin{array}{l}\text { total chol. }(\%) \\
<5.2 \mathrm{mmol} / 1\end{array}$ & $\begin{array}{l}\text { total chol./ } \\
\text { HDL-chol. }(\%)<5\end{array}$ \\
\hline Czech Republic & $55-64$ & 67 & 25 & 66 & 51 & 43 & 66 \\
\hline Romania & $\begin{array}{l}55-64 \\
65-74 \\
75-84\end{array}$ & $\begin{array}{l}77 \\
61 \\
12\end{array}$ & $\begin{array}{l}55 \\
43 \\
75\end{array}$ & $\begin{array}{r}62 \\
74 \\
100\end{array}$ & $\begin{array}{l}39 \\
36 \\
15\end{array}$ & $\begin{array}{l}64 \\
66 \\
85\end{array}$ & $\begin{array}{l}80 \\
80 \\
80\end{array}$ \\
\hline Slovakia & $\begin{aligned} & 55-64 \\
& 65-74 \\
& 75-84 \\
& \geq 85 \\
&\end{aligned}$ & & $\begin{array}{l}41(\mathrm{n}=2,817) \\
42(\mathrm{n}=1,510) \\
49(\mathrm{n}=381) \\
50(\mathrm{n}=14)\end{array}$ & $\begin{aligned} 80(\mathrm{n} & =1,746) \\
80(\mathrm{n} & =843) \\
83(\mathrm{n} & =211) \\
100(\mathrm{n} & =9)\end{aligned}$ & & $\begin{array}{l}55(\mathrm{n}=1,693) \\
62(\mathrm{n}=795) \\
69(\mathrm{n}=232) \\
67(\mathrm{n}=9)\end{array}$ & $\begin{array}{l}69(\mathrm{n}=1,183) \\
76(\mathrm{n}=417) \\
78(\mathrm{n}=113) \\
67(\mathrm{n}=3)\end{array}$ \\
\hline Austria & $\begin{aligned} & 55-64 \\
& 65-74 \\
& 75-84 \\
\geq & 85\end{aligned}$ & $\begin{array}{l}81 \\
45 \\
47 \\
20\end{array}$ & $\begin{array}{l}34 \\
29 \\
34 \\
26\end{array}$ & $\begin{array}{l}73 \\
85 \\
77 \\
95\end{array}$ & $\begin{array}{r}9 \\
10 \\
8 \\
4\end{array}$ & $\begin{array}{l}44 \\
60 \\
57 \\
75\end{array}$ & $\begin{array}{r}44 \\
50 \\
100 \\
75\end{array}$ \\
\hline Greece $^{b}$ & $\begin{array}{l}65-74 \\
75-84\end{array}$ & $\begin{array}{r}126 \\
38\end{array}$ & $\begin{array}{l}33 \\
36\end{array}$ & $\begin{array}{l}55 \\
71\end{array}$ & $\begin{array}{r}102 \\
43\end{array}$ & $\begin{array}{l}57 \\
50\end{array}$ & $\begin{array}{l}69 \\
76\end{array}$ \\
\hline
\end{tabular}

${ }^{a}$ Reference values. ${ }^{\text {b }}$ Raw data not available for recalculation. 


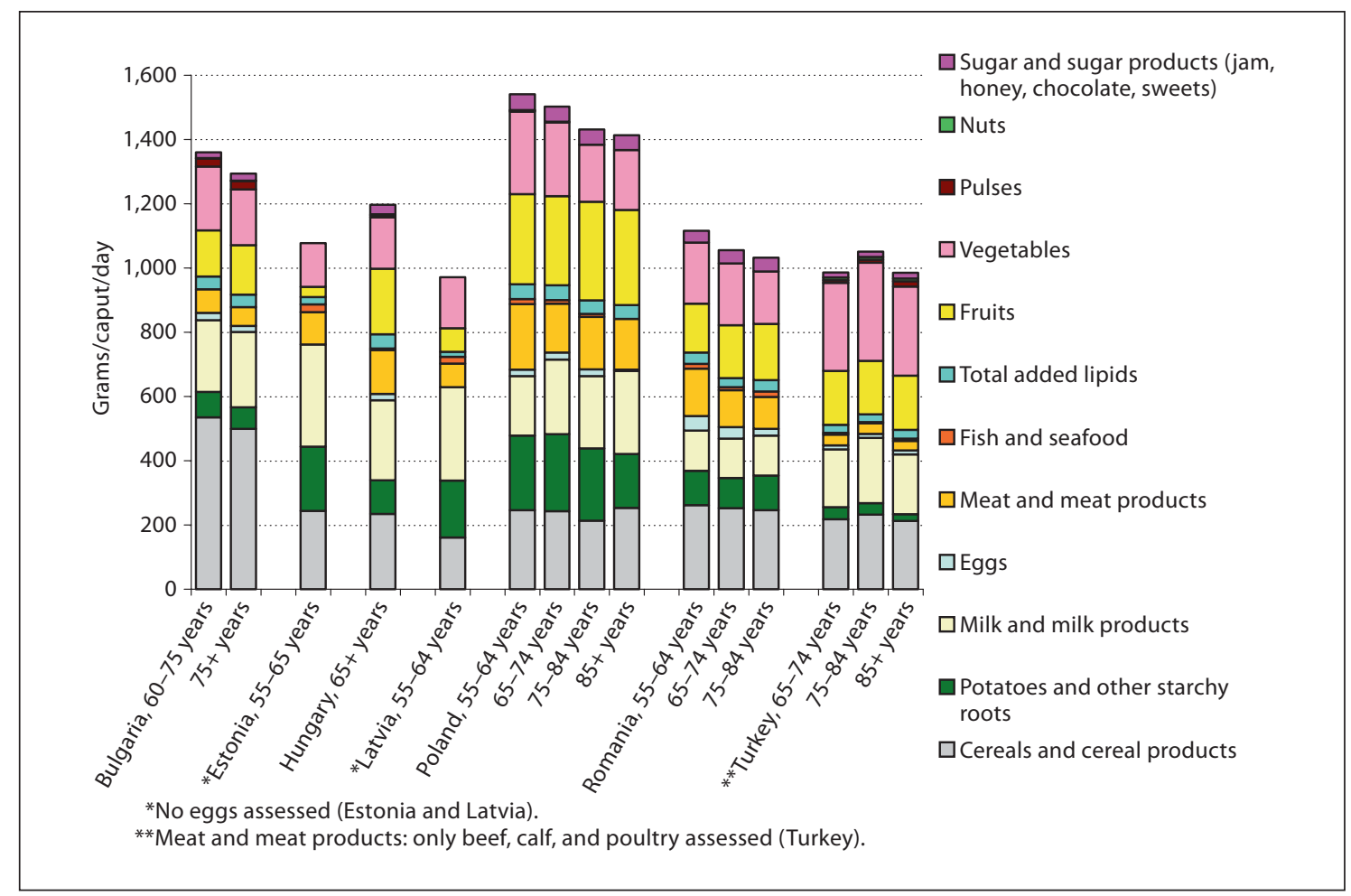

Fig. 1. Food intake of Eastern/Baltic European women (in age groups).

Table 6. Methods and periods of dietary assessment in studies of comparative evaluation

\begin{tabular}{lclll}
\hline Country $^{\text {a }}$ & Age group, years & n, F/M & Methods & Year(s) of survey \\
\hline Bulgaria & $\geq 60$ & $307 / 287$ & 24 -hour recall & 1998 \\
Estonia & $55-65$ & $190 / 126$ & 24 -hour recall & 1997 \\
Hungary & $\geq 65$ & $159 / 93$ & 24 -hour recall & 2003 \\
Latvia & $55-64$ & $496 / 356$ & 24 -hour recall & 2000 \\
Poland & $\geq 55$ & $467 / 318$ & 24 -hour recall & 2000 \\
Romania & $55-84$ & $150 / 90$ & 24 -hour recall & 2003 \\
Turkey & $\geq 65$ & $640 / 468$ & $3 \times 24$-hour recall & $2003-2004$ \\
Austriab & $\geq 55$ & $555 / 87$ & 24 -hour recall, Quant. FFQ & 2002 \\
Germany & $\geq 65$ & $789 / 583$ & 3 -day estimated record, Quant. FFQ & $1997-1998$ \\
Greece & $\geq 55$ & $31 / 235$ & Quant. FFQ & $2001-2002$ \\
Spain & $55-74$ & $213 / 180$ & 24 -hour recall (2 nonconsecutive days) & $1997-1998$ \\
\hline
\end{tabular}

$\mathrm{F}=$ Female; $\mathrm{FFQ}=$ food frequency questionnaire; $\mathrm{M}=$ male.

${ }^{a}$ Dietary intake was assessed by qualitative FFQ that could not be considered in intake quantity calculations in Czech Republic, Slovakia, Slovenia, Belgium and Greece.

${ }^{\mathrm{b}}$ Food intake data were not separated to sex, no raw data available.

${ }^{\mathrm{c}}$ Nutrient intake data only. 
was too high, especially saturated fats. Ranges of nutrient intake in 'new' and 'old' EU Member countries were generally comparable. In both regions, the same nutrients had to be categorized as 'too low' or 'too high' in daily intake. One essential exception is sodium intake which is clearly higher in Eastern/Baltic countries (especially in men) and probably due to a higher consumption of table salt. Figure 5 summarizes the dietary nutrient intake of both sexes in relation to the respective recommendation, stratified to region.

Interestingly, German senior citizens consumed nonalcoholic drinks more frequently than Polish and Spanish elderly resulting in a higher fluid intake (data not shown). Dietary habits followed the classical scheme of 3 major meals per day. In Estonia and Turkey, a higher percentage of the elderly had only 2 meals per day. Interestingly, there were no differences in the use of nutrient supplements in the two regions.

\section{Discussion}

In total, 69 studies on nutrition and lifestyle of elderly people have been performed within the last years in $\mathrm{Eu}-$ rope. Interestingly, the number of reported studies was comparable in the 'old' and 'new' member states (4.7 vs. 4.4 studies per country), demonstrating that topics like dietary habits, food consumption and their relation to health status were on the research agenda in all European regions. As expected, the great majority of the studies assembled in the 'new' member states were performed before joining the EU. Thus, acute developments with respect to availability of foods, costs of living etc. are probably not mirrored.

Using the criteria laid down in AgeingNutrition, only 36 studies (of 69 traced) were qualified for consideration in our evaluation. Most of the 'nonqualified' studies were excluded due to the fact that they were too old, too small and, most importantly, not focused on seniors (inappropriate age groups). Apparently, in all participating countries senior citizens are still not the major target of epidemiological research.

It was not surprising that study designs including subject recruitment, data assessment methods and management as well as the number and quality of variables evaluated varied broadly. Consequently, the list of parameters for a comparative evaluation had to be limited to those assessed in at least 7 (of 15) countries. To avoid a 'national bias' only one study was chosen from each participating country for comparative evaluation $(n=15)$. When

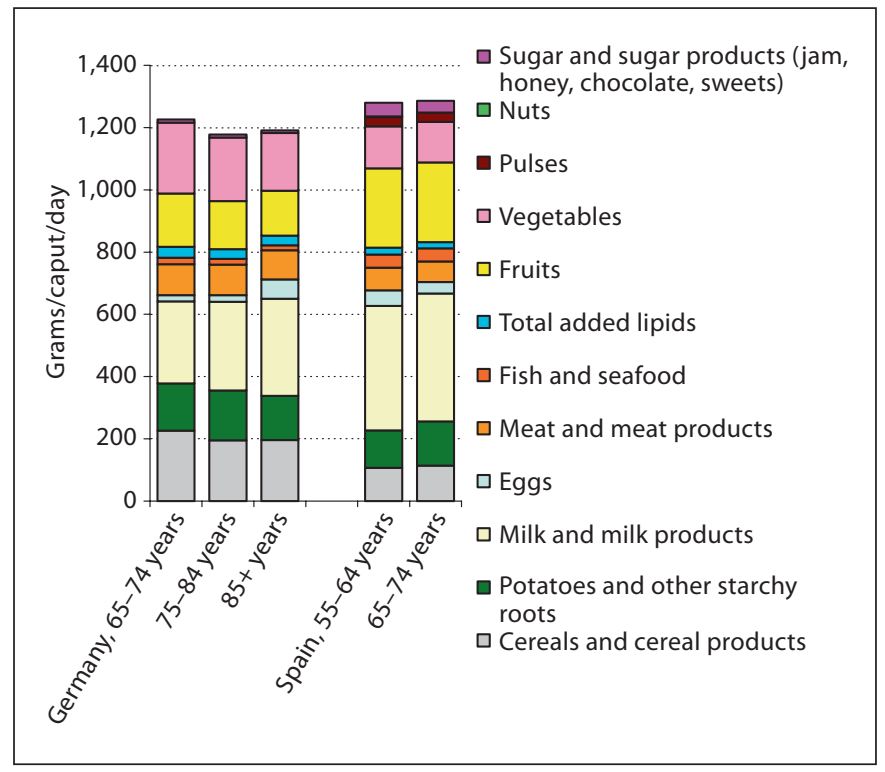

Fig. 2. Food intake of German and Spanish women (in age groups).

more than one study from a specific country was available, we chose the most comprehensive and recent report. It must be kept in mind that some sample sizes are rather small (e.g. table 6).

Reliability and exactness of data are depending on various factors like recruitment method, sample size, qualification of staff, period of data assessment (seasonal influences) and probably financial support [4]. A specific problem is the use of food databases for calculating nutrient intake. Since there is no 'European' database available, national food composition tables were used. It cannot be excluded that the basis of food composition tables are different and, thus, results of calculations vary within broader ranges.

The diet of a population can change considerably during one decade [4], although this might apply to a lesser degree to older people than to the younger, more trendorientated generations. Anyhow, the decade of assessment has to be kept in mind when comparing food intake data from the late 1990s with more recent data, as, for example, the variety of available foods might have changed especially in the 'new' member states.

Nutritional behavior and lifestyle are generally not different in 'old' and 'new' member states: overweight and obesity is the central problem. Mean BMI values of same age groups are similar in all countries studied (data not shown). BMI values were classified to the cut-off 


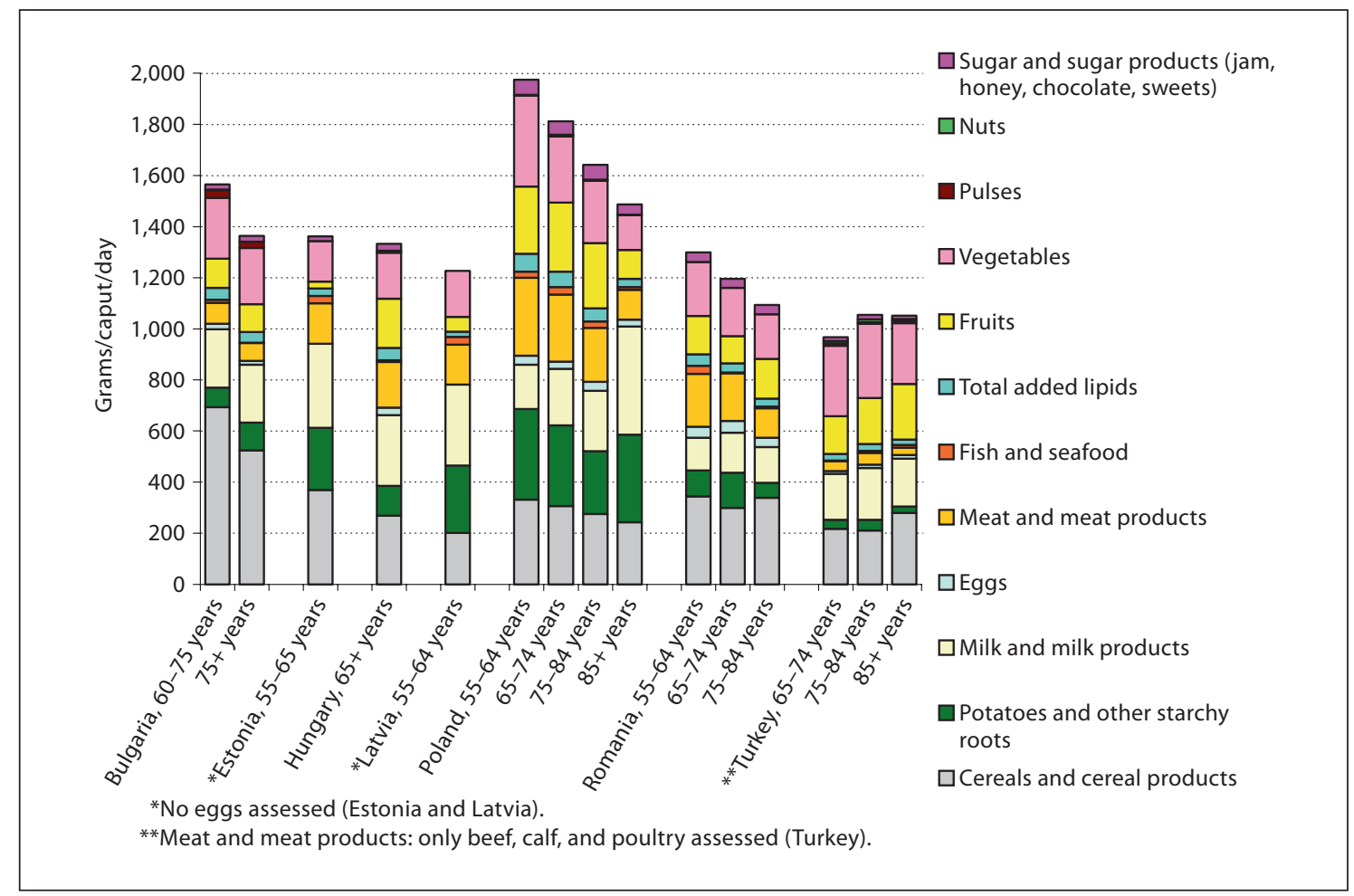

Fig. 3. Food intake of Eastern/Baltic European men (in age groups).

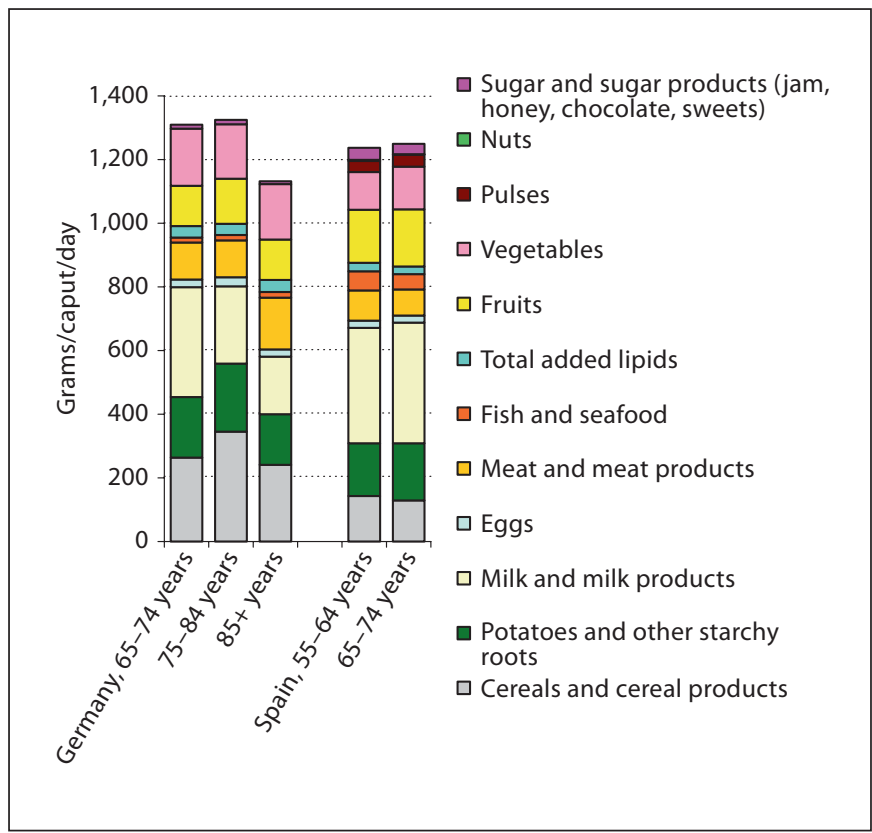

Fig. 4. Food intake of German and Spanish men (in age groups).

AgeingNutrition Project

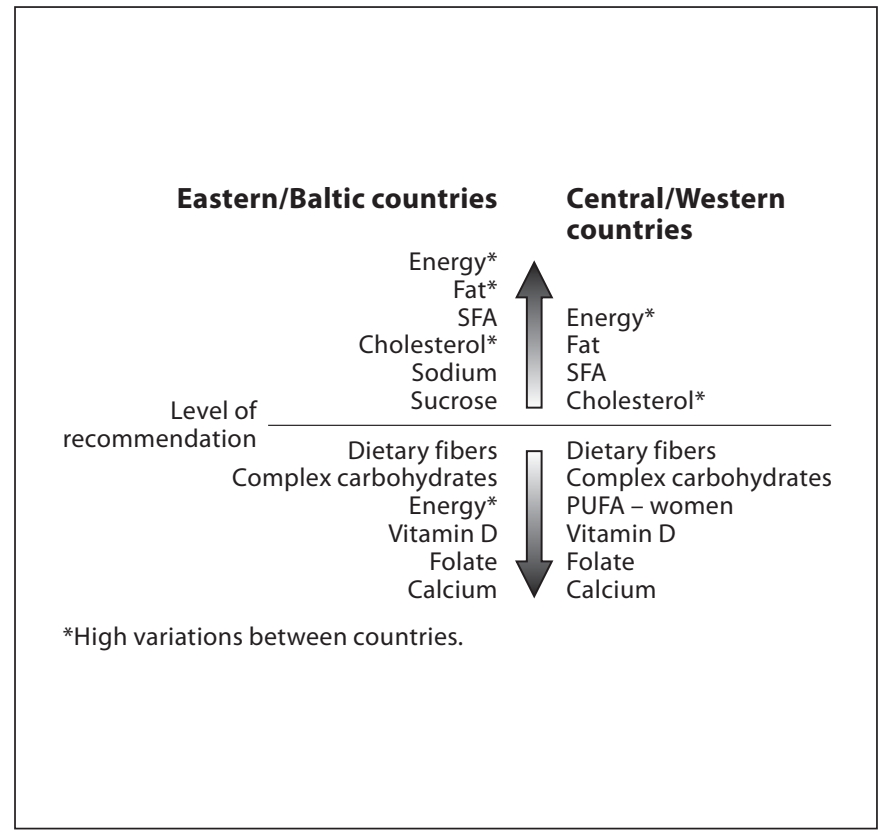

Fig. 5. Overview on dietary nutrient intake of European elderly (both sexes), in relation to the respective recommended level.

Ann Nutr Metab 2008;52(suppl 1):62-71 
Table 7a. Energy, macro- and micronutrient intake in European women ${ }^{1}$

\begin{tabular}{|c|c|c|c|}
\hline & $\begin{array}{l}\text { Eastern/Baltic } \\
\text { region } \\
\text { min-max }\end{array}$ & $\begin{array}{l}\text { Central/West- } \\
\text { ern region }{ }^{3} \\
\min -\max \end{array}$ & $\begin{array}{l}\text { Recommended } \\
\text { intake women } \\
>65 \text { years }\end{array}$ \\
\hline Energy, MJ & $4.9-10.8$ & $6.2-8.8$ & $7.5^{\mathrm{a}} / 7.3^{\mathrm{d}}$ \\
\hline Protein, \%E & $13-18$ & $14-17$ & $10-15^{\mathrm{c}}$ \\
\hline $\mathrm{CHO}, \% \mathrm{E}$ & $46-55$ & $43-47$ & $>55^{\mathrm{b}}$ \\
\hline Sucrose, \%E & $6-15$ & $\sim 9$ & $<10^{\mathrm{C}}$ \\
\hline Dietary fiber, g/day & $14-25$ & $16-25$ & $>25^{\mathrm{b}}$ \\
\hline Fat, $\% \mathrm{E}$ & $32-40$ & $35-43$ & $<30^{\mathrm{b}}$ \\
\hline $\mathrm{SFA}, \% \mathrm{E}$ & $11-15$ & $10-19$ & $<10^{\mathrm{b}}$ \\
\hline PUFA, \%E & 4-11 & 4-5 & $6-10^{b}$ \\
\hline Cholesterol, mg/day & $119-622$ & $118-403$ & $<300^{c}$ \\
\hline Vitamin $D, \mu g /$ day & $0.5-2.7$ & $3.0-4.7$ & $10^{\mathrm{a}}$ \\
\hline Folate, $\mu \mathrm{g} /$ day & $124-244$ & $157-251$ & $400^{\mathrm{b}}$ \\
\hline Calcium, mg/day & $529-835$ & $649-940$ & $>800^{\mathrm{b}}$ \\
\hline Iron, mg/day & $7.5-19.9$ & $10.2-14.9$ & $8^{\mathrm{d}}$ \\
\hline Sodium, g/day & $2.0-5.3$ & $1.3-2.4$ & $0.6-3.5^{\mathrm{d}}$ \\
\hline \multicolumn{4}{|c|}{$\begin{array}{l}{ }^{\text {a }} \text { DACH } 2000 \text { [11]. b Eurodiet } 2000 \text { [12]. c WHO } 2003 \text { [13]. } \\
\text { SCF } 1993 \text { [14]. } \\
{ }^{1} \text { Data are means of population subgroups. } \\
2 \text { Data from Bulgaria, Estonia, Hungary, Latvia, Poland, Ro- } \\
\text { ania, Turkey. } \\
{ }^{3} \text { Data from Austria, Germany, Greece, Spain (energy only). } \\
\text { CHO = Carbohydrates; PUFA = polyunsaturated fatty acids; } \\
\text { FA = saturated fatty acids. }\end{array}$} \\
\hline
\end{tabular}

points of 20 and 30 [7] (table 3a, b). A BMI of more than $30 \mathrm{~kg} / \mathrm{m}^{2}$ is known as a risk factor for developing chronic diseases such as CVD or diabetes mellitus [8]. Low BMI values (less than 20) reflect low body reserves and possibly malnutrition especially in older persons [5], and might indicate serious health risks as might be signs of an ongoing as yet undiagnosed disease. Since in most of the studies height and weight were actually measured by the investigators, the data obtained can be compared with previous assessments. In both the AgeingNutrition and the SENECA study, prevalence of obesity (BMI exceeding 30) was high in the younger study population (aged $70-75$ years), up to $25 \%$ and more, in some countries. In AgeingNutrition, prevalence of obesity was observed to be greater than $10 \%$ in all countries and nearly all age groups (table $3 \mathrm{a}, \mathrm{b}$ ). When mean prevalence of extreme $\mathrm{BMI}$ values is calculated for both regions, $\mathrm{BMI} \geq 30$ is more prevalent in Eastern/Baltic Europe (30\% of women, $22 \%$ of men) than in Central/Western countries $(21 \%$ of women, $17 \%$ of men). These Central/Western data are similar to findings of the follow-up of the SENECA study:
Table 7b. Energy, macro- and micronutrient intake in European men $^{1}$

\begin{tabular}{lccl}
\hline & $\begin{array}{l}\text { Eastern/Baltic } \\
\text { region } \\
\text { min-max }\end{array}$ & $\begin{array}{l}\text { Central/West- } \\
\text { ern region } \\
\text { min-max }\end{array}$ & $\begin{array}{l}\text { Recommended } \\
\text { intake men } \\
>65 \text { years }\end{array}$ \\
\hline Energy, MJ & $5.6-11.5$ & $7.1-11.0$ & $9.5^{\mathrm{a}} / 9.2^{\mathrm{d}}$ \\
Protein, \%E & $12-19$ & $11-17$ & $10-15^{\mathrm{c}}$ \\
CHO, \%E & $43-61$ & $41-50$ & $>55^{\mathrm{b}}$ \\
Sucrose, \%E & $6-14$ & $7-11$ & $<10^{\mathrm{c}}$ \\
Dietary fiber, g/day & $19-29$ & $15-26$ & $>25^{\mathrm{b}}$ \\
Fat, \%E & $27-41$ & $34-40$ & $<30^{\mathrm{b}}$ \\
SFA, \%E & $11-15$ & $8-20$ & $<10^{\mathrm{b}}$ \\
PUFA, \%E & $4-11$ & $4-9$ & $6-10^{\mathrm{b}}$ \\
Cholesterol, mg/day & $138-718$ & $108-466$ & $<300^{\mathrm{c}}$ \\
Vitamin D, $\mu$ g/day & $0.7-4.0$ & $3.0-5.7$ & $10^{\mathrm{a}}$ \\
Folate, $\mu$ g/day & $135-281$ & $151-355$ & $400^{\mathrm{b}}$ \\
Calcium, mg/day & $540-930$ & $635-1,024$ & $>800^{\mathrm{b}}$ \\
Iron, mg/day & $9.1-22.3$ & $10.0-16.5$ & $9^{\mathrm{d}}$ \\
Sodium, g/day & $2.5-6.6$ & $1.5-3.0$ & $0.6-3.5^{\mathrm{d}}$ \\
\hline
\end{tabular}

${ }^{a}$ DACH 2000 [11]. ${ }^{b}$ Eurodiet 2000 [12]. ${ }^{c}$ WHO 2003 [13]. d SCF 1993 [14].

${ }^{1}$ Data are means of population subgroups.

${ }^{2}$ Data from Bulgaria, Estonia, Hungary, Latvia, Poland, Romania, Turkey.

${ }^{3}$ Data from Austria, Germany, Greece, Spain (energy only).

$\mathrm{CHO}=$ Carbohydrates; PUFA = polyunsaturated fatty acids; SFA $=$ saturated fatty acids

$22 \%$ of women and $15 \%$ of men were classified obese [7]. A BMI $<20$ was prevalent in $2 \%$ of both genders in the Eastern/Baltic region and in Central/Western men $(6 \%$ prevalence in Central/Western women). In SENECA, similar prevalence rates (3\% of men and $6 \%$ of women) were observed. Our data can be cautiously interpreted that Central/Western European elderly are tendentiously more slender than Eastern/Baltic elderly. In general, prevalence of underweight increased and the prevalence of obesity decreased with age.

Compared to SENECA data $[9,10]$, mean blood lipid profiles (table 4) show considerably lower total cholesterol concentrations, suggesting that general cholesterol status might have improved recently in European elderly. HDL-cholesterol status of elderly women assessed was better than in men, as also observed in the SENECA study.

Food intake has been assessed using varying methods (table 6) which hampers comparative evaluation. Not every food item has been included in the assessment in every country (e.g. in Turkey only selected types of meat 
were assessed and in Latvia, no breads or rolls were included). As data are missing, food intake is underestimated in those countries and also nutrients intake might be biased. This fact is for example mirrored in figures 1-4 showing large differences in the amount of food intake per day. Nevertheless, a decrease in food intake with age may be derived from national data.

The results of AgeingNutrition can only be judged as an estimate but should stimulate further research work as well as political activities to improve nutrition and lifestyle in the European elderly population. For future multinational nutrition and health monitoring supported by the EU, it is strongly advised to employ standardized methods and tools.

\section{Disclosure Statement}

The AgeingNutrition Project has been financially supported by the European Commission (EC), Health \& Consumer Protection Directorate General, Directorate C - Public Health and Risk Assessment - within the Work Plan 2003 (GHP/2003; grant agreement No 2003113 SI2.379589). However, this report represents the views of the authors. These views have not been adopted or in any way been approved by the Commission and do not necessarily represent the view of the EC or the Directorate General for Health and Consumer Protection. The EC does not guarantee the accuracy of the data included in this study, nor does it accept responsibility for any use made thereof.

\section{References}

1 WHO: Keep fit for life: meeting the nutritional needs of older persons. Geneva, WHO, 2002.

-2 Volkert D: Nutrition and lifestyle of the elderly in Europe. J Public Health 2005;13:5661.

-3 Haveman-Nies A, de Groot LC, van Staveren WA: Dietary quality, lifestyle factors and healthy ageing in Europe: the SENECA study. Age Ageing 2003;32:427-434.

4 ENHR: European Nutrition and Health Report 2004. Basel, Karger, 2004.

5 Bauer JM, Volkert D, Wirth R, Vellas B, Thomas D, Kondrup J, Pirlich M, Werner H, Sieber CC: Diagnostik der Mangelernährung des älteren Menschen. Ergebnisse eines internationalen Experten-Meetings der BANSS-Stiftung. Dtsch Med Wochenschr 2006;131:223-227.
6 Beck A, Kritz H, Müller M, Silberbauer K, Sinzinger H: Cholesterin. 2. ACCC 2002, Konsensus-Statement. CliniCum, 2002.

7 de Groot LCPGM, Perdigao AL, Deurenberg P: Longitudinal changes in anthropometric characteristics of elderly Europeans. SENECA Investigators. Eur J Clin Nutr 1996; 50(suppl 2):S9-S15.

8 WHO: Obesity: preventing and managing the global epidemic. Report of a WHO consultation. WHO Technical Report Series No. 894. Geneva, WHO, 2000.

-9 Kafatos A, Schlienger JL, Deslypere JP, Ferro-Luzzi A, Cruz JA: Nutritional status: serum lipids. Euronut SENECA investigators. Eur J Clin Nutr 1991;45(suppl 3):53-61.
10 GrunenbergerF,Lammi-KeefeCJ,Schlienger JL, Deslypere JP, Hautvast JG: Longitudinal changes in serum lipids of elderly Europeans. SENECA Investigators. Eur J Clin Nutr 1996;50(suppl 2):S25-S31.

11 D-A-CH: Referenzwerte für die Nährstoffzufuhr. Frankfurt, Umschau/Braus, 2000.

12 Eurodiet: Eurodiet core report; 2000. http:// eurodiet.med.uoc.gr/

13 WHO: Diet, nutrition, and the prevention of chronic diseases. Report of a joint WHO/ FAO expert consultation. WHO Technical Report Series No 916. Geneva, WHO, 2003.

14 SCF: Nutrient and energy intakes for the European Community. Luxembourg, Office for Official Publications of the European Communities, 1993. 